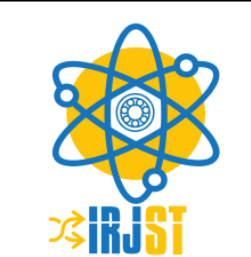

Available online at https://www.irjst.com/

International Research Journal of Science and Technology

ISSN: 2707-3955

DOI: https://doi.org/10.46378/irjst.2020.010204

\title{
Analysis of the Influence of High Technology Export to the Industry in Tanzania (2011-2017)
}

\section{Nuhu A. Sansa}

Guangxi University, Economics Department, Nanning, China

\begin{tabular}{lll}
\multicolumn{3}{l}{ Manuscript Status } \\
Received $\quad:$ & January 2020 \\
Accepted & $:$ & March 2020 \\
Published & $:$ & March 2020
\end{tabular}

Key Words

High Technology export

Industry

Influence

\begin{abstract}
Recent studies in Tanzania explore that high - tech manufactured exports in total manufactured exports, have deteriorated when measured by the CIP index. Regarding that fact, the present study is undertaken to assess the influence of High Technology exports to the industry from 2011 to 2017 in Tanzania. The study considers a simple regression method to assess and answer whether the High technology exports have influence on the industry or not. Because the other studies have been done in the period from 1966 to 2011, the World bank data for the period from 2011 to 2017 were applied by the study to assess the influence of high technology export to industry in Tanzania. During the process of evaluating the influence of high technology export to the industry in Tanzania, the study assumes high technology export to be the independent variable while the industry to be a dependent variable of the study. The findings of the study were quite interesting. The findings of the study revealed that there is a significant positive relationship between High technology export and industry GDP during the period from 2011 to 2017 in Tanzania. The results indicate that high technology exports have significant influence on the overall industry during the period from 2011 to 2017 in Tanzania.
\end{abstract}

Copyright (C) 2020: Nuhu A. Sansa. This is an open access distribution, and reproduction in any medium, provided Access article distributed under the Creative Commons Attribution License the original work is properly cited License, which permits unrestricted use.

Citation: Nuhu A. Sansa. "Analysis of the Influence of High Technology Export to the Industry in Tanzania (2011-2017)", International Research Journal of Science and Technology, 1 (2) 96-99, 2020.

\section{Introduction}

The Tanzania manufacturing sector performance and its contribution to the country's Gross domestic productivity is considered to be very low and less productive in comparison to the greatness of the sector towards transforming the of the entire economy. It was insisted that, "In Tanzania the performance of industry, and manufacturing in particular, is still perceived as weak compared with its potential growth and contributions to GDP, exports and employment creation" [1].

*Corresponding Author: Nuhu A. Sansa

Guangxi University, Economics Department, Nanning, China

Email : nuhusansa09@gmail.com
Tanzania manufacturing sector had gone through several challenges, mostly the challenge of infrastructure stand as the serious obstacle towards the transformation of the sector since Tanzania obtained its independence. It clearly identifies these challenges of the manufacturing sector to Tanzania, stating that, "The main factors restraining the manufacturing export performance and hence regional competitiveness are comparatively poor infrastructure. Tanzania is behind Kenya and, to some extent, Uganda when it comes to development of infrastructure factors such as roads, railways, air transport and telecommunications" [2].

The Tanzania manufacturing sector contribution to the country's gross domestic product is recorded to be 
behind the contribution of the agriculture and tourism sector in the country, which believed to be very poor and insignificant to transform the country to industrialization. It was clarified that, "The contribution of the manufacturing sector to the overall GDP of the country has averaged $8 \%$ over the last decade, however activities within the sector have been registering an annual growth of over $4 \%$ and the sector is currently the third most important to the Tanzania economy behind agriculture and tourism"[3].

Despite the Tanzania manufacturing sector contribution to the country Gross domestic product is low; the most interesting matter is the high-tech products contribution to the manufacturing sector which seems to decline continuously. Having these poor trends of high-tech products to contribute to the decline of manufacturing in Tanzania, in Tanzania no studies have been done to investigate the influence of the high-technology exports to the manufacturing sector.

\subsection{Motivation and Objective of the Study}

Recent studies in Tanzania explore that high-tech manufactured exports in total manufactured exports, have deteriorated when measured by the Comparative Industrial Performances (CIP) Index. "Tanzania needs to promote manufacturing of medium- and high-tech products. The shares of medium and high-tech MVA in total manufacturing, and medium- and high-tech manufactured exports in total manufactured exports, have deteriorated when measured by the CIP index" [1]. The deterioration of the high-tech manufactured exports pushed the study to investigate the influence of the high technology exports to the industry during the period from 2011 to 2017 in Tanzania.

\subsection{Literature Review}

The Tanzania manufacturing sector performance and its contribution to the country's gross domestic productivity is considered to be very low and less productive in comparison to the greatness of the sector towards transforming the entire economy. In Tanzania the performance of industry and manufacturing in particular, is still perceived as weak compared with its potential growth and contributions to GDP, exports and employment creation [1].

The Tanzania manufacturing sector contribution to the country's gross domestic product is recorded to be behind the contribution of the agriculture and tourism sector in the country, which was believed to be very poor and insignificant to transform the country to industrialization. The contribution of the manufacturing sector to the overall GDP of the country has averaged $8 \%$ over the last decade, however activities within the sector have been registering an annual growth of over $4 \%$ and the sector is currently the third most important to the Tanzania economy behind agriculture and tourism [3].

Literature pointed out the serious weakness of the Tanzania manufacturing sector as the sector is completely out to the Tanzania development history which believed to be the abnormal situation towards the industrialization agenda of the country. Tanzania ranks among the leading stars of the 'African growth miracle', but a sector that has been largely absent from the Tanzania success story is industry [4].

Tanzania's manufacturing sector has gone through several challenges, mostly the challenge of infrastructure stands as the serious obstacle towards the transformation of the sector since Tanzania obtained its independence. It clearly identifies these challenges of the manufacturing sector to Tanzania, stating that, "The main factors restraining the manufacturing export performance and hence regional competitiveness are: Comparatively poor infrastructure. Tanzania is behind Kenya and, to some extent, Uganda when it comes to development of infrastructure factors such as roads, railways, air transport and telecommunications [2]

The Tanzania manufacturing sector despite facing difficult obstacles including the long term challenges of the infrastructure the sector also has the fruitful side story where in the last decade the sector share of the manufactured goods doubled, As far as Tanzania's export structure is concerned, a positive story is starting to emerge. Tanzania has more than doubled the share of manufactured goods within exports in the last decade [5].

In order to pilot the recent Tanzania development activities, it has suggested that the role of the policies is inevitable and of top priority. It was insisted that the current development agenda, however, has brought industrial development back to be one of the policy priorities [6].

For the sustainable growth of the Tanzania manufacturing sector it has been suggested that measures should be undertaken to diversify the export from not depending on the few products with low value addition and having the serious price fluctuation in the market. Tanzania Industry Competitive Report reported that, "In fact, the current reliance of industrial growth on a few products that have low value addition and high price fluctuation calls for measures to diversify the export basket to lower the economy's vulnerability and to sustain growth [7]. 
The Tanzania manufacturing sector showed a good upward trend of growth and contribution in the year from 1961 to the year of 2014. It was revealed that the overall performance of export of Manufacturing shows an upward trend in nominal terms from USD 13.24 million in 1961 to USD 1,239.6 million in 2014 [8].

The Tanzania manufacturing sector counted to be the least developed among the African nations; however, recent sector performance shows the sector has gradually started to show the good direction [9]. The manufacturing sector in Tanzania is one of the least developed in Africa. However, strong and positive signs of recovery and growth have been observed over the last decade. The continued globalization of the world economy has been accompanied by generally rapid growth in international trade over much of the past few decades. [10].

Despite having the poor contribution to the national gross product the Tanzania manufacturing sector benefited from adopting the new technological capabilities from the foreign firms in Tanzania. It was described that, "Specifically, the study attempted to determine the extent to which the Tanzanian manufacturing sector has acquired technological capabilities as a result of the presence of foreign firms [11].

\section{Methodology}

The present study was undertaken to assess the influence of high technology exports to the industry from 2011 to 2017 in Tanzania. The study used Simple Regression method to assess and answer whether high technology exports have influence on the industry or not. Since, other studies have been done in the period of 1966 to 2010; the World Bank time series data from 2011 to 2017 were applied by the study to assess the influence of high technology exports to industry in Tanzania. During the process of evaluating the influence of high technology export to the industry in Tanzania the study assumed high technology export to be the independent variable while the industry to be a dependent variable of the study.

To assess the Influence of high technology exports to Industry GDP from 2011 to 2017 in Tanzania, the study formulated the following equation:

$\ln Y \mathrm{t}=\alpha 0+\beta 1$ H.T.Et $+\ldots \ldots \ldots \ldots . .(1)$

Where, $\ln Y$ is the natural log of Dependent Variable, H.T.E is High Technology Export. The $\alpha 0$ is constant, and $\beta 1$, is the coefficient parameter.

The Influence of High Technology Export to Industry GDP is estimated by:
INGDPt $=\alpha 0+\beta 1$ H.T.Et $+\mathrm{e} 2 \mathrm{t}$

Where, INGDPt is the natural log of Industry GDP.

4. Empirical Results and Discussion

To assess the Influence of high technology export to Industry GDP, the Study considered Descriptive and Analytical Quantitative Techniques to achieve the desired results.

The Influence of the High Technology Export to the Industry the results of the regression analysis show that there is a significant positive relationship between high technology export and Industry GDP from 2011 to 2017 in Tanzania. The Results are statistically significant with R-Squared 0.3542 having significant at the 1 percent critical value. The coefficient for high technology export is $0.09(\mathrm{t}=1.97, \mathrm{p}<.001)$. This Implies that for each additional increase in high technology export, Industry GDP increases by 0.09 points. The results indicate that high technology exports have significant influence on the overall Industry during the period of 2011 to 2017 in Tanzania (Table 1).

Table 1. Regression Results Between High Technology Export, and Industry GDP during from 2011 to 2017.

\begin{tabular}{lllll}
\hline Variables & C & SD & t- value & P \\
\hline H.T.exp & 0.09 & 0.04573 & 1.97 & 0 \\
C & 24.83 & & & 0 \\
R-squared & 0.3542 & & & \\
Adjusted r-square & 0.28 & & & \\
S.E.of regression & 0.4 & & \\
Number of observation =7 & & & \\
C-Co-efficient; SD-Standard Deviation; P-Probability & &
\end{tabular}

Appendix 01: Tanzania' High technology export, and Industry GDP for the period from 2011 to 2017 in Tanzania (Source: World Bank)

\begin{tabular}{lll}
\hline Year & H.T.Exp-X & Ind Gdp-Y \\
\hline 2011 & 5.904 & 26.382 \\
2012 & 11.35 & 25.399 \\
2013 & 6.722 & 25.447 \\
2014 & 3.387 & 25.142 \\
2015 & 0.853 & 24.487 \\
2016 & 2.32 & 24.858 \\
2017 & 2.565 & 25.1 \\
Sum & 33.101 & 176.815 \\
\hline
\end{tabular}

\section{Summary of the Findings}

The findings of the study revealed that there is a significant positive relationship between high technology export and Industry GDP from 2011 to 
Appendix 02: Regression Calculations between High Technology Exports, and Industry GDP from 2011 to 2017 in Tanzania.

\begin{tabular}{llllll}
\hline Year & H.T.Exp-X & Ind Gdp-Y & $\mathrm{X}^{2}$ & $\mathrm{Y}^{2}$ & $\mathrm{XY}$ \\
\hline 2011 & 5.904 & 26.382 & 34.857216 & 696.009924 & 155.759328 \\
2012 & 11.35 & 25.399 & 128.8225 & 645.109201 & 288.27865 \\
2013 & 6.722 & 25.447 & 45.185284 & 647.549809 & 171.054734 \\
2014 & 3.387 & 25.142 & 11.47179 & 632.120164 & 85.155954 \\
2015 & 0.853 & 24.487 & 0.727609 & 599.613169 & 20.887411 \\
2016 & 2.32 & 24.858 & 5.3824 & 617.920164 & 57.67056 \\
2017 & 2.565 & 25.1 & 6.579225 & 630.01 & 64.3815 \\
Sum & 33.101 & 176.815 & 233.026024 & 4468.332431 & 843.188137 \\
\hline
\end{tabular}

(Source: Calculated by Author from Appendix 01).

2017 in Tanzania. The results indicated high technology exports have significant influence on the overall Industry during the period 2011 to 2017 in Tanzania.

\section{Conclusions}

The present study was undertaken to assess the influence of high technology exports to the Industry from 2011 to 2017 in Tanzania. The findings of the study revealed that there is a significant positive relationship between high technology export and Industry GDP during the period 2011 to 2017 in Tanzania. The results indicated high technology exports have significant influence on the overall Industry during the period 2011 to 2017 in Tanzania.

\section{References}

[1]. Mbelle.A, \& Kabanda. H, (2018). Recent progress towards industrialisation in Tanzania1. Supporting Economic Transformation.

[2]. Mbelle .A.V.Y, (2000). The Manufacturing sector in Tanzania. A study by the Confederation of Tanzania Industries (CTI) and the Confederation of Danish Industries (DI) in association with Dr. A. V. Y. Mbelle of the Economics Department, University of Dares-Salaam. December 2000.

[3]. Intelligence. M, (2020). Manufacturing industry in Tanzania: Analysis of consumption and production trends of several key industries (2020 - 2025).

[4]. John. M. (2016) : Industry in Tanzania: Performance, prospects, and public policy, WIDER Working Paper, No. 2016/5, ISBN 978-92-9256-048-5, The United Nations University World Institute for Development Economics Research (UNU-WIDER), Helsinki.
[5]. Kahyarara. G, (2013). Tanzania Manufacturing Export and Growth: A cointegration Approach. University of Dar-esSalaam, College of Social Sciences, Economics Department.

[6]. Wangwe. S, Mmari. D, Aikaeli. J, Rutatina.N, Mboghoina.T, \& Kinyondo.A, (2014): The Performance of the Manufacturing Sector in Tanzania: Challenges and the Way Forward. Working Paper No. 22 . REPOA Report.

[7]. Tanzania Industry Competitive Report, (2012). United Nations Industrial Development Organization.

[8]. Mbelle .A.V.Y. (2016). Manufacturing and Transformation in a developing country context: Assessing Policy response in changing policy paradigm-Tanzania (Revised version, 16.4.2016).

[9]. Ministry of Industry \& Trade United Republic of Tanzania, (2011). Integrated Industrial Development Strategy 2025 December 2011.

[10]. Balchin. N, Gelb.S, Kennan.J, Martin.H , Velde. D.W, \& Carolin W. R., (2016). Developing export base manufacturing in sub saharan Africa. Supporting Economic Transformation (SEC).

[11]. Diyamett. B., \& Mutambla. M (2015). Foreign direct investment and local technological capabilities in least developed countries: some evidence from the Tanzanian manufacturing sector. Science, Technology and Innovation Policy Research Organisation (STIPRO), Dares Salaam, Tanzania.

[12]. Tanzania Country Report, (2014). East African's manufacturing sector. Promoting Technology Innovation, Productivity and Linkages. Africa Development Group Report 2014. 